\title{
Open or just Fragmented? Mobilization through Open Source Action Repertoires in the Blockchain Social Movement
}

\author{
Claire Ingram Bogusz \\ Stockholm School of Economics \\ Gothenburg University \\ claire@clairebogusz.com
}

\author{
Jonas Valbjørn Andersen \\ ITU Copenhagen \\ jova@itu.dk
}

\begin{abstract}
The Blockchain social movement not only opposed the economic system in the post-2009 financial crisis years, it provided a tangible technological alternative, built in computer code and using Open Source (OS) principles.

The social movement mobilized using familiar OS structures and activities as action repertoires. Although this openness encouraged mobilization, this ran the risk of losing control, as individuals used the OS code for their own purposes, outside the scope of the social movement.

The use of $O S$ action repertoires provided ways to coordinate, vent and build consensus. Further, the resulting dissent, when it occurred made the movement more relevant by extending the movement and mobilizing individuals in complementary areas, driven by economic incentives. The OS repertoire of open entrepreneurship also facilitated mobilization, making the movement more influential.
\end{abstract}

\section{Introduction}

The emergence of the cryptocurrency Bitcoin occurred at a time when the financial system of the day was facing a crisis of trust: Existing elites and institutions had been criticized for taking advantage of ordinary individuals (often called the $99 \%$ ), in order to make money for the $1 \%$, including through bail-outs [1]. Crucially, many pointed to a systemic failure in the financial system as enabling this problematic behavior, namely centralization e.g. [2]. The decentralized Open Source (OS) technology behind Bitcoin, the Blockchain, was framed as providing a technical alternative "as a system for electronic transactions without relying on [third party] trust" [3]. In so doing, it 1) offered an OS technology as an alternative to existing ways of conducting transactions, which 2) allowed for more transparency in how and when new money was created, and 3) built upon OS repertoires when it came to both organizing and governance [4]. This digitally mediated form of trust emerged at the same time as other anti- establishment economic social movements like Occupy Wall Street [5], and other digital and decentralized alternatives in finance, like crowdfunding [6], [7] and peer-to-peer loans [8].

Although many activists are skeptical of new technologies [9], technologies can be both a tool in a social movement, for instance when activists rally behind a cancer treatment technology [10], or the outcome of activism, as in the case of animal rights activism leading to technological alternatives to animal testing [11]. That a technology might embody the processes through which activism occurs, rather than as a tool or an outcome of activism is perhaps not surprising, given advances in understanding the materiality of the digital in organizing [12], [13].

Mobilization with the aim of reaching a critical mass is a common goal for social movements. In this case, for Blockchain technologies to become an alternative to this one element of the financial system would require not just the technology, but adoption by a critical mass. This would frame the technology as a viable alternative to the status quo and legitimize the cause [14], while also attracting resources that would support activism [15]. Activists typically mobilize through organizational and protest structures, known as action repertoires [16].

Social movements (SMs), or "networks of informal interactions between a plurality of individuals, groups and/or organizations, engaged in political or cultural conflicts, on the basis of shared collective identities" $[17$, p. 1] often have a champion who guides the movement [18], harnesses and generates knowledge [19], and attracts other resources [15]. However, an OS movement does not necessarily have a single champion. Instead, it relies on openness to attract resources and knowledge [20]. However, this approach does not prevent resources and knowledge from leaving the community or being used for unsanctioned ends [21]. This has been highlighted as a paradox: openness encourages adoption, use and innovation through re-use and repurposing, encouraging an OS project (and thus a social movement) to grow. However, this may come at the expense of control and the ability to set collectivelevel goals [22]. 
That this openness is double-edged makes its implications for the social movement unclear. On the one hand, individuals in an OS social movement might pursue similar goals, albeit in different ways and with different incentives. On the other hand, this openness may lead to fragmentation. Thus, understanding how OS social movement repertoires are employed, and for what ends, is critical to understanding how these repertoires affect the social movement. We thus ask the question:

How does the use of open source repertoires to mobilize affect the Blockchain social movement?

This paper builds on literatures around OS communities, e.g. [20], [22], [23], social movement repertoires [18], [24], and the dynamics around a social movement mediated by a technology [10], [11]. More specifically, it considers the effect of mobilization through OS repertoires on 1) the social movement of Blockchain's core aims, namely to highlight the flaws of the existing economic system and present a viable alternative, and 2) what happens when a technology mediates a social movement.

To answer this question, we undertook a mixed methods study of the social movement, based on forum data spanning a 6-year period, triangulated against other sources. In what follows, we discuss how OS features provide a familiar tactical repertoire, and how they are used to mobilize in the name of the Blockchain social movement. We then turn to analyzing the case of the Blockchain social movement.

\section{The OS social movement of Blockchain}

Social movements typically frame a crisis like 2008/2009 financial crisis the as a political opportunity [5], [25]. This particular crisis was characterized as, at best, an unfortunate accident in a complex system [26], or at worst a failure of market economics [27], in a system dominated by elites [2]. At its core, it exposed the failings in which the formerly legitimate financial system operated. Blockchain proponents argued not just that social system had failed, but that there was a problem with their material systems, namely the fact that they were 1) centralized, and thus 2) controlled by elites with vested interests. It then offered an alternative in the form of a new technology.

Extant research has pointed to how digital technologies have transformed social movements in one of two ways: either by 1) affecting the process of activism through the use of digital tools, most notably social media, or 2) prompting new technologies, increasingly digital, as a result of activism. These two areas of research are summarized in Table 1.

\subsection{OS, Digital Technologies and Social Movements}

The Blockchain social movement, in a novel turn of events, chose to oppose the economic system by not just protesting against it as others had done e.g. [28], but by providing an (open source) alternative to how the economic system might run. In the process it made use of a repertoire of familiar narratives and actions to promote the technology, with an emphasis on mobilization.

Gathering a mass following and aligning individuals with the social movement's aims is known as mobilization. Mobilization is pursued for three reasons; first, for the movement's narratives and actions to be perceived as influential and relevant [29], [30], second to mobilize resources [31], and third to overcome the impasse where there is no individual incentive to act (or even incentives for individual members of the collective to 'free ride'[32]), known as collective action.

\begin{tabular}{|c|c|c|}
\hline \multicolumn{3}{|c|}{ Table 1: The impact of digital technologies on social movement processes and outcomes } \\
\hline Description & Case & Example Reference \\
\hline \multirow{6}{*}{$\begin{array}{l}\text { Digital technologies } \\
\text { present new ways of } \\
\text { mobilising and } \\
\text { acting }\end{array}$} & $\begin{array}{l}\text { New forms of collective engagement during the Gulf of } \\
\text { Mexico oil spill }\end{array}$ & e.g. Vaast et al. 2017 \\
\hline & $\begin{array}{l}\text { Online activism at } 2009 \text { G20 London Summit during the } \\
\text { global (2009) financial crisis }\end{array}$ & e.g. Bennett and Segerberg 2011 \\
\hline & Bypassing gatekeepers in the Tahrir Square uprising & e.g. Tufekci and Wilson 2012 \\
\hline & Informal learning during \#OccupyWallStreet & e.g. Gleason 2013 \\
\hline & $\begin{array}{l}\text { Digital empowerment during protests against a rare earth } \\
\text { refinery plant }\end{array}$ & e.g. Leong et al. 2015 \\
\hline & Digital action repertoires at Amnesty International & e.g Selander and Jarvenpaa 2016 \\
\hline \multirow{4}{*}{$\begin{array}{l}\text { Technological } \\
\text { solutions as a result } \\
\text { of social movements }\end{array}$} & Technological alternatives to animal testing & e.g. Weisskircher 2019 \\
\hline & Digital Education through MOOCs & e.g. Longstaff 2017 \\
\hline & Creation of new (technological) knowledge & $\begin{array}{l}\text { e.g. Casas-Cortés, Osterweil, and } \\
\text { Powell } 2008\end{array}$ \\
\hline & $\begin{array}{l}\text { Democratisation of entrepreneurial finance through } \\
\text { crowdfunding }\end{array}$ & $\begin{array}{l}\text { e.g. Gleasure 2015; Ingram } \\
\text { Bogusz, Teigland, and Vaast } 2019\end{array}$ \\
\hline
\end{tabular}


Supporters of a social movement are more likely to mobilize around an issue where there are existing, familiar, organizational structures and familiar forms of protest, or action repertoires [16]. OS repertoires are well-established when it comes to software and hardware projects. However, to our knowledge, such a project has never formed the basis for a deliberate and organized social movement, even if they have indirectly shaped societies. Coordinating mechanisms in OS have come to be well-recognized and, within their communities, legitimate [33].

Open source software projects are often described not only as the most successful examples of online collaboration [41]-[43], but fast collaboration [44] by distributed and self-motivated groups [45], [46]. Crucially, these efforts are not only open and collaborative - but voluntary, implying that economic incentives are seldom behind OS collaborations [44], [46]. The exception to this is the increased involvement of corporate actors in OS projects [47], and the emergence of so-called "open entrepreneurs" who commercialize additions to OS code or build spin-outs [48], [49].

Among the most established of these repertoires are coordination through developer mailing lists [20], [47] forum discussions [50], code sharing [51], and code forking [52], [53]. In Table 2, we give descriptions of these repertoires in extant literature, describe their aims and typical outcomes, and give exemplar references.

Having presented the theoretical background to our study, we turn now to presenting our case and findings.

\begin{tabular}{|c|c|c|c|c|}
\hline \multicolumn{5}{|c|}{ Table 2. Summary of extant OS Action Repertoires } \\
\hline $\begin{array}{l}\text { OS Action } \\
\text { Repertoire } \\
\end{array}$ & Description & Intention & Outcome & $\begin{array}{l}\text { Exemplar } \\
\text { references }\end{array}$ \\
\hline $\begin{array}{l}\text { Developer } \\
\text { mailing list } \\
\text { discussion }\end{array}$ & $\begin{array}{l}\text { Developer-specific } \\
\text { records of areas of } \\
\text { concern and } \\
\text { development within } \\
\text { the project }\end{array}$ & $\begin{array}{l}\text { To connect } \\
\text { developers with } \\
\text { interest, and often } \\
\text { active, in a project }\end{array}$ & $\begin{array}{l}\text { Bug management, record of } \\
\text { version control, and } \\
\text { developer issue discussion }\end{array}$ & $\begin{array}{l}\text { e.g. Lindberg et al., } \\
\text { 2016; Shaikh \& } \\
\text { Vaast, 2016; West \& } \\
\text { O'Mahony, } 2008\end{array}$ \\
\hline $\begin{array}{l}\text { Public forum } \\
\text { discussions }\end{array}$ & $\begin{array}{l}\text { Areas for public } \\
\text { discussion of an OS } \\
\text { project. Typically } \\
\text { includes developers, } \\
\text { but also users who } \\
\text { are not developers } \\
\end{array}$ & $\begin{array}{l}\text { Public discussion } \\
\text { forum for interaction } \\
\text { between developers, } \\
\text { users, and other } \\
\text { interested actors }\end{array}$ & $\begin{array}{l}\text { Overlap with developer } \\
\text { mailing lists, but with } \\
\text { considerable content from } \\
\text { non-developers (e.g. user } \\
\text { issues, requests for advice, } \\
\text { etc) }\end{array}$ & $\begin{array}{l}\text { e.g. Dahlander \& } \\
\text { Magnusson, 2008; } \\
\text { Demil \& Lecocq, } \\
\text { 2006; Ingram Bogusz } \\
\text { \& Morisse, } 2018\end{array}$ \\
\hline Code Sharing & $\begin{array}{l}\text { Computer code } \\
\text { shared, often through } \\
\text { a public repository } \\
\text { like GitHub, typically } \\
\text { with an OS licence in } \\
\text { place }\end{array}$ & $\begin{array}{l}\text { To enable the reuse } \\
\text { of OS code }\end{array}$ & $\begin{array}{l}\text { OS code is shared and } \\
\text { reused, both by OS and non- } \\
\text { OS projects (although the } \\
\text { latter is controversial) }\end{array}$ & $\begin{array}{l}\text { e.g. Bergquist \& } \\
\text { Ljungberg, 2001; } \\
\text { Dahlander \& } \\
\text { Magnusson, 2008; } \\
\text { Hemetsberger \& } \\
\text { Reinhardt, 2009 } \\
\end{array}$ \\
\hline Code Forking & $\begin{array}{l}\text { Computer code } \\
\text { repurposed, often } \\
\text { (but not always) } \\
\text { through a public } \\
\text { repository }\end{array}$ & $\begin{array}{l}\text { To enable the reuse } \\
\text { and repurposing of } \\
\text { code in new projects, } \\
\text { whether with or } \\
\text { without sanction of } \\
\text { the original project }\end{array}$ & $\begin{array}{l}\text { OS code is re-used, creating } \\
\text { new versions of a project, } \\
\text { for instance when there is a } \\
\text { disagreement between } \\
\text { developers or in the interest } \\
\text { of a hobby }\end{array}$ & $\begin{array}{l}\text { e.g. Andersen \& } \\
\text { Ingram Bogusz, } \\
\text { 2019; Fleming \& } \\
\text { Waguespack, 2007; } \\
\text { Nyman \& Lindman, } \\
2013\end{array}$ \\
\hline $\begin{array}{l}\text { Code / } \\
\text { Feature } \\
\text { Additions }\end{array}$ & $\begin{array}{l}\text { Addition of new } \\
\text { features, for instance } \\
\text { a new work package } \\
\text { or user interface }\end{array}$ & $\begin{array}{l}\text { New code modules } \\
\text { are built upon the } \\
\text { original project, } \\
\text { adding new } \\
\text { functionality }\end{array}$ & $\begin{array}{l}\text { Additions to the OS code, } \\
\text { typically reliant on either } \\
\text { the original OS code or a } \\
\text { forked version. These may } \\
\text { be free or paid-for additions } \\
\text { (open entrepreneurship) }\end{array}$ & $\begin{array}{l}\text { e.g. Dempsey et al., } \\
2002 ; \\
\text { Krishnamurthy, } \\
\text { 2002; Yetis-Larsson } \\
\text { et al., } 2015\end{array}$ \\
\hline
\end{tabular}

\section{Case and Research Design}

Interest in the Blockchain in recent years has largely centered on how fast it has grown in value-from around 30 (US) cents per Bitcoin in January 2011, to around over 9000 USD in July 2020, with a peak of nearly 20000 USD per bitcoin in late 2017. At the same time, the underlying Blockchain technology has been appropriated by Organisations and governments to build new systems, for instance R3-Corda by banks and TradeLens by Maersk and IBM to track shipping supply chains. While second and third generations of the technology are often centrally controlled, the original Bitcoin Blockchain was not. 
The fact that the original Bitcoin blockchain was not centrally controlled is important to understanding why it emerged. This decentralized design, and with it a correlation between control and interest in the system was thought to be a way to protect the users of the system [53].

In our case, a tension emerged between the original intentions of those who built the system, namely, to keep it fully decentralized, and the realization that this decentralization was ineffective and prevented the system from evolving to meet increased use and demand.

\section{Data collection and analysis}

We collected conversation threads from the Bitcoin Discussion section of the online forum bitcointalk.org. Bitcointalk.org is a forum dedicated to discussions around Bitcoin, primarily in English. It is among the most prominent forums used by Blockchain enthusiasts. However, unlike mainstream forums like Reddit.com, it is often used specifically by Blockchain professionals meaning that interactions on Bitcointalk.org are particularly linked to the development of the Bitcoin community and the underlying Blockchain. Furthermore, the Bitcoin Discussion section contains threads that are both general and specific in nature; for instance, threads around the technicalities of the Blockchain and mining as well as discussions of the ideological underpinnings of the community.

The data consists of 314551 digital trace records covering 13032 conversation threads in the period from
October 2010 to September 2015. This period was selected because it contains at least five salient events in which the Blockchain community was forced to mobilize including the Harakury fraud incident, the hacking and theft from the bitcoin exchange Mt.Gox, the introduction of bitcoin as a digital currency, the splitting of the community over block size, and the introduction of credit, merchant, and sidechain additions to the Blockchain infrastructure.

Our starting point was to treat the forum data as representing interests of those using/maintaining Bitcoin and underlying infrastructure. We used computational methods to cluster the most common search terms, which we then coded manually to identify key topics of discussion. We triangulated the importance of these topics against our own knowledge and media archives [63].

We conducted a qualitative-computational analysis of the collected digital trace records of interactions among members of the Bitcoin community. Data analysis was conducted in three steps: First, we applied the term frequency based topic modelling algorithm [61] Latent Dirichlet Allocation (LDA) [62] to generate descriptive coding of observed interactions that identify the use of OS repertoires in the Blockchain community.

The second step was to parse these descriptive clusters and classify them, identifying distinct discussions of OS repertoires in the data, analogous to what is done in purely manual coding [53]. The third step involved linking the emerging OS repertoires to extant theory. These steps, and the methods used, are summarised in Table 3.

\begin{tabular}{|l|l|l|}
\hline \multicolumn{2}{|c|}{ Table 3. Overview of Analysis and Methods } \\
\hline Analytical step & Analytical technique & Analytical outcome \\
\hline 1. Initial coding for OS repertoire use & $\begin{array}{l}\text { Topic modelling using Latent } \\
\text { Dirichlet Allocation (LDA) }\end{array}$ & $\begin{array}{l}\text { Identified 45 issues mediated by OS } \\
\text { repertoires }\end{array}$ \\
\hline $\begin{array}{l}\text { 2. Axial coding for distinct OS } \\
\text { repertoire discussion and use }\end{array}$ & $\begin{array}{l}\text { Manual coding of topic clusters } \\
\text { resulting from the topic model }\end{array}$ & $\begin{array}{l}\text { Explication of five OS repertoires and } \\
\text { instantiation of 11 sub-repertoires }\end{array}$ \\
\hline 3. Theoretical coding & $\begin{array}{l}\text { Theoretical coding of the data to } \\
\text { unpack OS repertoire use }\end{array}$ & $\begin{array}{l}\text { Explanation of the effect of OS } \\
\text { repertoire use on the social } \\
\text { movement }\end{array}$ \\
\hline
\end{tabular}

\section{Findings}

We turn now to unpacking the OS repertoires that we see in the Blockchain movement (summarized in Table 4). Overall, we find that OS repertoires allow not only for coordination and shared-problem solving, consistent with extant OS research, but also that OS repertoires create incentives for individual-level activities that advance the goals of the larger movement, particularly through mobilization and by mollifying dissent by providing a space for ventilation.

\subsection{Developer mailing list and public forum discussions}

Public forums provided for the repertoires of consensusbuilding and for community members to express their frustrations, or what we call ventilation. Consensus- 
building was visible in how community members discussed concerns around country-level regulations, as well as how to respond to corruption within the Blockchain community. Sometimes this consensusbuilding was unsuccessful, with the conversations ending without consensus, as in the case of how to respond to dominant players, for instance miners in China:

It looks grim for BTC without China in the picture and you might say we don't need China other countries will acknowledge it and there will be mass adoption but look at the value of BTC now without China in the picture. China obviously is a big player and I can't see BTC hitting a new milestone or even hitting the peak of $\$ 1,300$ BTC but I hope I am wrong. What do you think?" (December 18, 2013, 10:54:17 AM)

At the same time, individuals used the space to ventilate, without the intention of building consensus, as happened during the bankruptcy of a sizeable Bitcoin exchange called Mt.Gox:

"...looks like green adresses are failing, theese things are non confirmation adresses, witch should be protected by MTGOX.... because the bitcoin network did not confrm yet, BITSTAMP does not seem to have this problem , NOR does BTC china!so it is NOT a general bitcoin problem.but a gox green adress problem.so THIS IS A GOX ONLY PROBLEM! , not bitcoin! if it was a general btc error Bitstamp would have had the same problem and so would have BTC china!" (February 10, 2014, 10:50:20 AM)

\subsection{Code Sharing and Debugging}

Delving into the activities performed by developers (in consultation with the wider community, our analysis pointed to how Code Sharing and Debugging were used in practice. This repertoire, drawing on common OS practices, saw developers coordinate with one another and community members (sub-repertoire developer coordination) around code streamlining, maintenance and minor improvements. We observed two significant instances where this occurred, namely in discussions around how efficient Bitcoin was compared to other Blockchains, and how to respond to Bitcoin's perceived inefficiencies, particularly difficulties scaling to reach rising demand:

"By default Bitcoin will not created blocks larger than $250 \mathrm{~kb}$ even though it could do so without a hard fork. We have now reached this limit. Transactions are stacking up in the memory pool and not getting cleared fast enough.

What this means is, you need to take a decision and do one of these things:

- $\quad$ Start your node with the -blockmaxsize flag set to something higher than $250 \mathrm{~kb}$, for example blockmaxsize $=1023000$. This will mean you create larger blocks that confirm more transactions. You can also adjust the size of the area in your blocks that is reserved for free transactions with the -blockprioritysize flag.

- Change your nodes code to de-prioritize or ignore transactions you don't care about, for example, Luke-Jr excludes SatoshiDice transactions which makes way for other users.

- Do nothing.

If everyone does nothing, then people will start having to attach higher and higher fees to get into blocks until Bitcoin fees end up being uncompetitive with competing services like PayPal." (March 06, 2013, 09:44:20 AM)

Of note is the fact that there is a connection between developer coordination and later code-level changes in response to that coordination. In other words, there was overlap between the repertoire of developer coordination and Feature Additions and Code Forking.

However, while developer coordination allowed the movement to advance when it came to maintenance issues both code sharing and debugging and hardware debugging facilitated improvement in user, rather than code, experience, by making sure that existing functions worked as they should - and finding and remedying errors and incompatibilities where they occurred.

\subsection{Code and Feature Additions}

Code-level changes which did not amount to minor instances of streamlining or maintenance done through developer coordination instead amounted to Code and Feature Additions, or a repertoire through which individuals could rely on the underlying movement to build something that they could commercialize. There were many instances of this through entrepreneurial diversification, or what has elsewhere been called open entrepreneurship [48], [49]. Some of this diversification responded to market concerns from the community, while other instances focused on making the community, and thus the movement, more relevant for outsiders: 


\begin{tabular}{|c|c|c|c|c|}
\hline \multicolumn{5}{|c|}{ Table 4. How OS repertoires mediate mobilisation, characteristics, instances, and impact } \\
\hline $\begin{array}{l}\text { OS Action } \\
\text { Repertoire }\end{array}$ & $\begin{array}{l}\text { Enabled } \\
\text { mobilisation } \\
\text { through sub- } \\
\text { repertoires of }\end{array}$ & Characteristics & Examples & $\begin{array}{l}\text { Impact on } \\
\text { movement }\end{array}$ \\
\hline \multirow{6}{*}{$\begin{array}{l}\text { Developer } \\
\text { mailing list } \\
\text { and public } \\
\text { forum } \\
\text { discussions }\end{array}$} & \multirow{3}{*}{$\begin{array}{l}\text { Consensus- } \\
\text { building }\end{array}$} & \multirow{3}{*}{$\begin{array}{l}\text { Forum discussion over } \\
\text { two or more periods } \\
\text { without diverging }\end{array}$} & Boycotting of Bitcoin XT & \multirow{3}{*}{$\begin{array}{l}\text { Apparent consensus } \\
\text { on how to respond to } \\
\text { perceived social and } \\
\text { technical threats }\end{array}$} \\
\hline & & & Response to regulations & \\
\hline & & & $\begin{array}{l}\text { Response to perceived } \\
\text { corruption of Bitcoin.org }\end{array}$ & \\
\hline & \multirow{2}{*}{$\begin{array}{l}\text { Unsuccessful } \\
\text { consensus- } \\
\text { building }\end{array}$} & \multirow{2}{*}{$\begin{array}{l}\text { Forum discussion } \\
\text { terminates after one } \\
\text { period, never translates } \\
\text { into concrete code-based } \\
\text { proposal }\end{array}$} & $\begin{array}{l}\text { Attitude (and possible } \\
\text { response to) dominance } \\
\text { of Chinese miners }\end{array}$ & \multirow{2}{*}{$\begin{array}{l}\text { Failure of community } \\
\text { to agree on response } \\
\text { to perceived social } \\
\text { and technical threats }\end{array}$} \\
\hline & & & $\begin{array}{l}\text { Attitude (and possible } \\
\text { response to) Bitcoin } \\
\text { scams }\end{array}$ & \\
\hline & Ventilation & $\begin{array}{l}\text { Self-contained hub of } \\
\text { discussion, without } \\
\text { consensus or response }\end{array}$ & $\begin{array}{l}\text { Response to Mt.Gox } \\
\text { bankruptcy }\end{array}$ & $\begin{array}{l}\text { Short-term response } \\
\text { prompted by external } \\
\text { events }\end{array}$ \\
\hline \multirow{4}{*}{$\begin{array}{l}\text { Code Sharing } \\
\text { and } \\
\text { Debugging }\end{array}$} & $\begin{array}{l}\text { Developer } \\
\text { coordination }\end{array}$ & $\begin{array}{l}\text { Discussion over two or } \\
\text { more periods without } \\
\text { diverging, spans both } \\
\text { forums and developer } \\
\text { mailing lists (links to dev } \\
\text { posts in forum data) }\end{array}$ & $\begin{array}{l}\text { Comparison with } \\
\text { alternatives to Bitcoin } \\
\text { (e.g. Ether) }\end{array}$ & $\begin{array}{l}\text { Coordination around } \\
\text { improving on existing } \\
\text { applications of code, } \\
\text { in line with social and } \\
\text { practical } \\
\text { considerations } \\
\end{array}$ \\
\hline & \multirow{2}{*}{$\begin{array}{l}\text { Code Sharing and } \\
\text { Debugging }\end{array}$} & \multirow{2}{*}{$\begin{array}{l}\text { Reference to pieces of } \\
\text { code in trying to remedy } \\
\text { errors/bugs }\end{array}$} & Shared Code & \multirow{3}{*}{$\begin{array}{l}\text { Support from other } \\
\text { community members } \\
\text { in keeping the } \\
\text { technical elements of } \\
\text { the social movement } \\
\text { running }\end{array}$} \\
\hline & & & UI output & \\
\hline & $\begin{array}{l}\text { Hardware } \\
\text { debugging }\end{array}$ & $\begin{array}{l}\text { Seeking support for } \\
\text { hardware problems that } \\
\text { affect code operations }\end{array}$ & Hardware failure & \\
\hline \multirow{6}{*}{$\begin{array}{l}\text { Code / } \\
\text { Feature } \\
\text { Additions }\end{array}$} & \multirow{5}{*}{$\begin{array}{l}\text { Realised (open) } \\
\text { entrepreneurship }\end{array}$} & \multirow{5}{*}{$\begin{array}{l}\text { Realised addition to } \\
\text { underlying code base, } \\
\text { separate applications } \\
\text { visible in discussion and } \\
\text { verified through } \\
\text { triangulation with other } \\
\text { sources }\end{array}$} & Merchant applications & \multirow{5}{*}{$\begin{array}{l}\text { Innovation within } \\
\text { technology, making } \\
\text { use of code, that: } \\
\text { 1) Keeps the social } \\
\text { movement } \\
\text { relevant, or } \\
\text { Facilitates increased } \\
\text { mobilisation }\end{array}$} \\
\hline & & & Consumer applications & \\
\hline & & & Online Payments & \\
\hline & & & Investment & \\
\hline & & & Currency hedging & \\
\hline & $\begin{array}{l}\text { Unrealised } \\
\text { entrepreneurship }\end{array}$ & $\begin{array}{l}\text { Proposed but unrealised } \\
\text { addition to underlying } \\
\text { code (verified through } \\
\text { triangulation) }\end{array}$ & Giving credit & $\begin{array}{l}\text { May lead to code fork } \\
\text { to enable unrealized } \\
\text { addition }\end{array}$ \\
\hline \multirow{6}{*}{ Code Forking } & \multirow[b]{3}{*}{$\begin{array}{l}\text { Sub-optimality } \\
\text { correction }\end{array}$} & \multirow[b]{3}{*}{$\begin{array}{l}\text { Concrete code-based } \\
\text { proposals to change or } \\
\text { add to existing code after } \\
\text { community consensus }\end{array}$} & $4 \mathrm{mb}$ block size change & \multirow{3}{*}{$\begin{array}{l}\text { Split to the technology } \\
\text { in the name of } \\
\text { unresolved ideological } \\
\text { differences, typically } \\
\text { leads users to leave } \\
\text { the original } \\
\text { movement }\end{array}$} \\
\hline & & & $2 \mathrm{mb}$ block size change & \\
\hline & & & Bitcoin Core & \\
\hline & & Concrete code-based & BitcoinXT & \multirow{3}{*}{$\begin{array}{l}\text { Technical } \\
\text { implementation of } \\
\text { code that creates new } \\
\text { communities, and may } \\
\text { both new and existing } \\
\text { movement members }\end{array}$} \\
\hline & Ideological pivots & $\begin{array}{l}\text { proposals that change } \\
\text { existing code after } \\
\text { community consensus, } \\
\text { typically controversial }\end{array}$ & Alternative Blockchains & \\
\hline & Spin-offs & $\begin{array}{l}\text { Concrete code-based } \\
\text { proposals necessitate a } \\
\text { new project, with or } \\
\text { without consensus, } \\
\text { typically controversial }\end{array}$ & $\begin{array}{l}\text { New Blockchains with } \\
\text { different characteristics, } \\
\text { notably Ethereum }\end{array}$ & \\
\hline
\end{tabular}


“...We would like to hear from the community what are the most annoying frustrating stuff you have with Bitcoin and would love to get a solution for? Feel free to talk about any problem, even if it seems unsolvable or too abstract (e.g. Bitcoin is not safe enough for the average user) Edit:After reading all the replies, I feel confident summarizing that the \#1 problem of Bitcoin is probably lack of adoption. And the main reasons of lack of adoption are probably ease of use and insufficient security. We are a team of entrepreneurs and software developers that are going to spend the next following months-year on developing a new product.One of the most appealing markets for us is the Bitcoin market.We will try to learn us much as possible from your replies and try to tackle the problems head on" (June 27, 2015, 03:19:37 AM)

Many of these additions were hard to implement as they would require changes to the character of the community, and systemic changes to the code - not just reliance on the existing code, as in the case of a credit feature addition:

"If there's no backstop such as the one which central banks provided in 2008, you could potentially see a rapid contraction of credit down to zero and complete collapse of the entire system as everyone tries to exchange their credit for something tangible." (December 28, 2012, 02:34:03 PM)

These failed attempts at adding features instead led to code forking.

\subsection{Code Forking}

It is well-known that participants in OS software projects disagree, whether on what to do, or how to do it [44]. This is true of the Blockchain social movement too. When attempts at developer coordination or community consensus-building fails, members of the social movement repurpose the existing code in new projects [52], [53]. In this case, code forking as a repertoire occurs as one of three sub-repertoires.

First, sub-optimality correction refers to dramatic changes to the underlying code ([53]), in the name of improving the existing movement. In other words, those who engage in sub-optimality correction do so in the name of supporting and making the social movement more relevant:

"Sometimes bottleneck happening,too muchunconfirmed transaction when the blocksize only limited for $1 \mathrm{mb}$, and it'll affect on your transaction, need to wait longer than usual and sometimes it'd took time about 1 hour or more, it's sure a problem i guess, i'm sure you don't want to wait about $\sim$ lhour when your client is waiting for the transaction. I can catch up your point dude, you are absolutely right that sometimes the transaction of bitcoin have been delaying even troubled.
But $i$ hoe that problem will fix by developers of bitcoin . " (May 27, 2016, 11:15:24 AM)

In contrast, ideological pivots are not about improving on the existing movement, but rather making the movement relevant by expanding it to new user groups. In the process, existing users may leave-or remain members of the original project while also supporting a new project. Typically, the disagreements here are of an ideological character-with practical implications. The typical case is that of Bitcoin XT: as a result of increased use, the Bitcoin blockchain had slowed due to increased demand. One proposed solution was to increase the size of each block, from $1 \mathrm{mb}$ to $4 \mathrm{mb}$. This would reduce the number of miners able to run the software (owing to issues around processing power), centralizing control of the blockchain, but would increase the Blockchain's transaction handling capacity in a new version of the blockchain known as BitcoinXT. This centralization was an ideological issue in the community as it was described as making the movement less democratic, hence the ideological split.

Lastly, Spin-offs occurred when users or developers decided to start a new project for reasons that were largely unrelated to the perceived effectiveness of the existing blockchain, but rather around its capabilities or scope. In other words, they wished to be able to do more with the underlying technology than the existing movement allowed for.

Having discussed how OS repertoires manifested in the social movement of Blockchain (table 4), we turn now to discussing the implications of these findings for our understandings of digital social movements, and the interplay between OS and a social movement.

\section{Discussion: OS action repertoires}

\subsection{OS Repertoires for Coordination}

Within both software e.g. [64], [65] and music production [24], OS movements have re-shaped competition dynamics and business models and made products free and accessible online - thus closing digital divides across the globe. In this paper, we not only highlight that OS repertoires provide familiar organizational structures and actions for coordination and activity [16], but also unpack how these OS repertoires are employed to mobilize in the social movement of the Blockchain.

We thus link the use of Blockchain mobilization activities to existing, familiar, OS repertoires. These Blockchain-specific uses of OS repertoires allow for mobilization in the social movement of Blockchain through developer coordination, code sharing and debugging, and hardware debugging. Further, OS forums are a context in which developers and movement 
participants can build consensus or just vent, providing not only a way to coordinate, but also ways for individuals to let off steam without undermining the larger movement.

Where this coordination fails, further OS repertoires help to hitch subsequent projects to the parent project through sub-optimality correction, ideological pivots and spin-offs, collectively referred to as part of the Code Forking repertoire.

Interestingly, the possibility to build upon the system through Feature Additions channels individuals to scope the system, making it both more relevant and more influential.

\section{2. (Open) Entrepreneurship mobilises}

As highlighted earlier, there is a tension between the openness of OS projects, which both attracts resources and knowledge [20] and drains them [21]. We see evidence of this in the social movement of Blockchain, albeit with largely positive outcomes, largely because the knowledge here is non-severable; reuse and repurposing of code need not detract from the original project-and users and developers can be involved in multiple projects if they so wish.

While it could have been the case that the activities of individual entrepreneurs would undermine the original project [22], [66], what we saw instead was that the use of OS repertoires allowed for coordination, when needed, avenues in which to vent frustration, and avenues to productively harness differences of (political) opinion, including ideological differences, in the form of code.

Thus, the use of open entrepreneurship serves not just the individuals who benefit economically from it, but the social movement as a whole. Not only does open entrepreneurship support the movement's pursuit of influence and relevance [29], [30], it facilitates the inward flow of resources by attracting new users and supporters, and even outside capital [31]. Lastly, it resolves collective action problems by creating economic incentives for action at an individual level that support the movement at the collective level [32].

\subsection{Digital Economic Social Movement}

The Blockchain social movement responded to perceived weaknesses in existing economic institutions. However, they not only offered alternative economic views of the world [67], [68], they built an entire alternative system in the form of code.

In so doing, participants relied on existing repertoires known from OS projects to coordinate and fine-tune the movement. Crucially, these repertoires also highlighted how economic incentives in OS projects lead to entrepreneurship [48]. In this case, this entrepreneurial drive led to feature addition, which kept the social movement relevant and even made it more appealing to would-be participants. This entrepreneurial drive also leads to the creation of new projects through ideological pivoting and spin-offs.

We submit that this harnessing of economic incentives within a digital social movement makes Blockchain not just a novel digital social movement that responds to a perceived economic failure, but rather an economic social movement-in which economic incentives mobilise and drive the movement itself, keeping it relevant, allowing it to scope, and mobilising new movement participants.

\section{Conclusion}

Overall, we find that the tension between mobilization and fragmentation is a driving mechanism that promotes mobilization and, with it, relevance and influence, in the economic social movement of Blockchain. Specifically, this mechanism operates through individual-level activities as participants in the social movement of Blockchain not only make use of pre-existing OS repertoires to coordinate, ventilate and build consensus around issues, but that the use of these repertoires helps to keep the movement relevant.

We further find that while the openness of a social movement based on OS principles may lead to a lack of control, what occurred in this case was that openness encouraged open entrepreneurship - mobilizing further in the name of the social movement.

Lastly, the use of entrepreneurship and the implied economic incentives that come with it suggest that Blockchain is not just a social movement in response to the perceived failings of the economic system, but a social movement with an economic character of its own, making it an economic social movement.

\section{References}

[1] G. Bruton, S. Khavul, D. Siegel, and M. Wright, "New Financial Alternatives in Seeding Entrepreneurship: Microfinance, Crowdfunding, and Peer-to-Peer Innovations," Entrep. Theory Pract., vol. 39, no. 1, pp. 9-26, Jan. 2015

[2] E. Engelen et al., "Misrule of experts? The financial crisis as elite debacle," Econ. Soc., vol. 41, no. 3, pp. 360-382, 2012.

[3] S. Nakamoto, "Bitcoin: A peer-to-peer electronic cash system," 2008.

[4] R. Beck, C. Müller-Bloch, and J. L. King, "Governance in the Blockchain Economy: A Framework and Research Agenda," J. Assoc. Inf. Syst., vol. forthcoming, 2018.

[5] W. L. Bennett and A. Segerberg, "Digital Media and the Personalization of Collective Action: Social Technology 
and the Organization of Protests against the Global Economic Crisis," Inf. Commun. Soc. , vol. 14, no. 6, pp. 770-799, 2011,

[6] R. Gleasure and J. Feller, "Emerging technologies and the democratisation of financial services: A metatriangulation of crowdfunding research," Inf. Organ., vol. 26, no. 4, pp. 101-115, 2016.

[7] C. Ingram Bogusz, R. Teigland, and E. Vaast, "Platform Use Takes More than Trust: Designed Legitimacy on a Crowdfunding Platform," Eur. J. Inf. Syst., vol. 28, no. 3, pp. 318-335, 2018.

[8] H. Yum, B. Lee, and M. Chae, "From the wisdom of crowds to my own judgment in microfinance through online peer-to-peer lending platforms," Electron. Commer. Res. Appl., vol. 11, no. 5, pp. 469-483, Sep. 2012

[9] K. Weber, H. Rao, and L. G. Thomas, "From streets to suites: How the anti-biotech movement affected German pharmaceutical firms," Am. Sociol. Rev., vol. 74, no. 1, pp. 106-127, 2009.

[10] D. J. Hess, "Technology- And product-oriented movements: Approximating social movement studies and science and technology studies," Sci. Technol. Hum. Values, vol. 30, no. 4, pp. 515-535, 2005

[11] M. Weisskircher, "New technologies as a neglected social movement outcome: The case of activism against animal experimentation," Sociol. Perspect., vol. 62, no. 1, pp. 59-76, 2019.

[12] W. J. Orlikowski and C. S. Iacono, "Research Commentary: Desperately Seeking the 'IT' in IT Research--A Call to Theorizing the IT Artifact," Inf. Syst. Res., vol. 12, no. 2, pp. 121-134, 2001

[13] P. M. Leonardi, "Digital materiality? How artifacts without matter, matter," First Monday, vol. 15, no. 6, 2010.

[14] F. W. Geels and B. Verhees, "Cultural legitimacy and framing struggles in innovation journeys: A culturalperformative perspective and a case study of Dutch nuclear energy (1945-1986)," Technol. Forecast. Soc. Change, vol. 78, no. 6, pp. 910-930, 2011

[15] S. Kaplan, "Framing contests: Strategy making under uncertainty," Organ. Sci., vol. 19, no. 5, pp. 729-752, 2008

[16] R. K. Garrett, "Protest in an Information Society: a review of literature on social movements and new ICTs," Information, Commun. Soc., vol. 9, no. 2, pp. 202-224, Apr. 2006

[17] M. Diani, "The concept of social movement," Sociol. Rev., vol. 40, no. 1, pp. 1-25, 1992.

[18] L. Selander and S. L. Jarvenpaa, "Digital action repertoires and transforming a social movement organization," MIS Q., vol. 40, no. 2, pp. 331-352, 2016,

[19] M. I. Casas-Cortés, M. Osterweil, and D. E. Powell, "Blurring boundaries: Recognizing knowledge-practices in the study of social movements," Anthropol. Q., vol. 81, no. 1, pp. 17-58, 2008

[20] M. Shaikh and E. Vaast, "Folding and unfolding: Balancing openness and transparency in open source communities," Inf. Syst. Res., vol. 27, no. 4, pp. 813-833, 2016

[21] K. Laursen and A. Salter, "The Paradox of Openness Appropriability and the Use of External Sources of Knowledge" 2005.

[22] L. Dahlander and D. M. Gann, "How open is innovation?," Res. Policy, vol. 39, no. 6, pp. 699-709, Jul.
2010 ,

[23] K. Laursen and A. J. Salter, "The paradox of openness: Appropriability, external search and collaboration," Res. Policy, vol. 43, no. 5, pp. 867-878, 2014.

[24] S. L. Jarvenpaa and K. R. Lang, "Boundary management in online communities: Case studies of the nine inch nails and ccmixter music remix sites," Long Range Plann., vol. 44, no. 5-6, pp. 440-457, 2011

[25] J. Reinecke, "Social Movements and Prefigurative Organizing: Confronting entrenched inequalities in Occupy London," Organ. Stud., vol. 39, no. 9, pp. 1299-1321, 2018,

[26] E. Engelen et al., After the great complacence: Financial crisis and the politics of reform. Oxford University Press, 2011.

[27] F. Roth, "The effect of the financial crisis on systemic trust," Intereconomics, vol. 44, no. 4, pp. 203-208, 2009.

[28] A. Segerberg and W. L. Bennett, "Social media and the organization of collective action: Using Twitter to explore the ecologies of two climate change protests," Commun. Rev., vol. 14, no. 3, pp. 197-215, 2011.

[29] E. W. Johnson, "Social Movement Size, Organizational Diversity and the Making of Federal Law," Soc. Forces, vol. 86, no. 3, pp. 967-993, 2008,

[30] B. Klandermans, "Mobilization and participation: Social-psychological expansisons of resource mobilization theory," Am. Sociol. Rev., pp. 583-600, 1984.

[31] J. D. McCarthy and M. N. Zald, "Resource mobilization and social movements: A partial theory," Am. J. Sociol., vol. 82, no. 6, pp. 1212-1241, 1977.

[32] T. Schelling, "Micromotives and macrobehavior. Nueva York." WW Norton \& Company, 1978.

[33] L. Dahlander and S. O'Mahony, "Progressing to the Center: Coordinating Project Work," Organ. Sci., vol. 22, no. 4, pp. 961-979, Aug. 2011

[34] E. Vaast, H. Safadi, L. Lapointe, and B. Negoita, "Social media affordances for connective action: An examination of microblogging use during the Gulf of Mexico oil spill," MIS Q. Manag. Inf. Syst., vol. 41, no. 4, pp. 11791206, 2017,

[35] Z. Tufekci and C. Wilson, "Social media and the decision to participate in political protest: Observations from Tahrir Square," J. Commun., vol. 62, no. 2, pp. 363-379, 2012.

[36] B. Gleason, "\# Occupy Wall Street: Exploring informal learning about a social movement on Twitter," Am. Behav. Sci., vol. 57, no. 7, pp. 966-982, 2013.

[37] C. Leong, S. L. Pan, S. Bahri, and A. Fauzi, "Digital enablement: social media in empowering the grassroot environmental movement of Malaysia," 2015.

[38] E. Longstaff, "Ritual in online communities: A study of post-voting in MOOC discussion forums," Int. J. Human-Computer Interact., vol. 33, no. 8, pp. 655-663, 2017.

[39] R. Gleasure, "Resistance to crowdfunding among entrepreneurs: An impression management perspective," $J$. Strateg. Inf. Syst., vol. 24, no. 4, pp. 219-233, 2015,

[40] C. Ingram Bogusz, R. Teigland, and E. Vaast, "Designed Entrepreneurial Legitimacy: The Case of a Swedish Crowdfunding Platform," Eur. J. Inf. Syst., vol. 28, no. 3, pp. 318-335, 2019.

[41] G. K. Lee and R. E. Cole, "From a Firm-Based to a Community-Based Model of Knowledge Creation: The Case 
of the Linux Kernel Development," Organ. Sci., vol. 14, no. 6, pp. 633-649, 2003,

[42] E. Von Hippel and G. Von Krogh, "Open source software and the 'private-collective' innovation model: Issues for organization science," Organ. Sci., vol. 14, no. 2, pp. 209$223+225,2003$,

[43] E. Von Hippel and G. Von Krogh, "Free revealing and the private-collective model for innovation incentives," $R$ D Manag., vol. 36, no. 3, pp. 295-306, 2006,

[44] S. K. Shah, "Motivation, governance, and the viability of hybrid forms in open source software development," Manage. Sci., vol. 52, no. 7, pp. 1000-1014, 2006.

[45] A. Hemetsberger and C. Reinhardt, "Collective development in open-source communities: An activity theoretical perspective on successful online collaboration," Organ. Stud., vol. 30, no. 9, pp. 987-1008, 2009,.

[46] E. Raymond, "The cathedral and the bazaar," Knowledge, Technol. Policy, vol. 12, no. 3, pp. 23-49, 1999.

[47] J. West and S. O'mahony, "The role of participation architecture in growing sponsored open source communities," Ind. Innov., vol. 15, no. 2, pp. 145-168, 2008,

[48] Z. Yetis-Larsson, R. Teigland, and O. Dovbysh, "Networked Entrepreneurs: How Entrepreneurs Leverage Open Source Software Communities," Am. Behav. Sci., vol. 59, no. 4, pp. 475-491, 2015.

[49] C. Ingram Bogusz and M. Morisse, "How infrastructures anchor open entrepreneurship: The case of Bitcoin and stigma," Inf. Syst. J., vol. 28, no. 6, pp. 11761212, 2018.

[50] C. Zhang, J. Hahn, and P. De, "Continued Participation in Online Innovation Communities: Does Community Response Matter Equally for Everyone?," Inf. Syst. Res., vol. 24, no. 4, pp. 1112-1130, Dec. 2013.

[51] M. Bergquist and J. Ljungberg, "The power of gifts: Organizing social relationships in open source communities," Inf. Syst. J., vol. 11, pp. 305-320, 2001.

[52] L. Nyman and J. Lindman, "Code Forking, Governance, and Sustainability in Open Source Software," Technol. Inf. Manag., no. January, pp. 7-12, 2013.

[53] J. V. Andersen and C. Ingram Bogusz, "Selforganizing in blockchain infrastructures: Generativity through shifting objectives and forking," J. Assoc. Inf. Syst., vol. 20, no. 9, pp. 1242-1273, 2019.

[54] A. Lindberg, N. Berente, J. Gaskin, and K. Lyytinen, "Coordinating Interdependencies in Online Communities: A Study of an Open Source Software Project," Inf. Syst. Res., vol. 27, no. 4, pp. 751-772, 2016.

[55] B. Demil and X. Lecocq, "Neither market nor hierarchy nor network: The emergence of bazaar governance," Organ. Stud., vol. 27, no. 10, pp. 1447-1466, 2006.

[56] L. Dahlander and M. G. Magnusson, "How do Firms Make Use of Open Source Communities?," Long Range Plann., vol. 41, no. 6, pp. 629-649, 2008.

[57] a. Hemetsberger and C. Reinhardt, "Collective Development in Open-Source Communities: An Activity Theoretical Perspective on Successful Online Collaboration," Organ. Stud., vol. 30, no. 9, pp. 987-1008, Sep. 2009.

[58] L. Fleming and D. M. Waguespack, "Brokerage, boundary spanning, and leadership in open innovation communities," Organ. Sci., vol. 18, no. 2, pp. 165-180, 2007.

[59] B. J. Dempsey, D. Weiss, P. Jones, and J. Greenberg, "Who is an open source software developer?," Commun. ACM, vol. 45, no. 2, pp. 67-72, 2002.

[60] S. Krishnamurthy, "Cave or community?: An empirical examination of 100 mature open source projects," First Monday, 2002.

[61] S. Debortoli, O. Müller, I. Junglas, and J. vom Brocke, "Text mining for information systems researchers: An annotated topic modeling tutorial," Commun. Assoc. Inf. Syst., vol. 39, no. 1, pp. 110-135, 2016.

[62] D. M. Blei, A. Y. Ng, and M. I. Jordan, "Latent dirichlet allocation," J. Mach. Learn. Res., vol. 3, no. 1, pp. 993-1022, 2003, doi: 10.1162/jmlr.2003.3.4-5.993.

[63] G. A. Bowen, "Naturalistic inquiry and the saturation concept: a research note," Qual. Res., vol. 8, no. 1, pp. 137-152, 2008.

[64] G. von Krogh and S. Spaeth, "The open source software phenomenon: Characteristics that promote research," J. Strateg. Inf. Syst., vol. 16, no. 3, pp. 236-253, Sep. 2007.

[65] U. Holtgrewe and R. Werle, "De-commodifying software?: Open source software between business strategy and social movement," Sci. Stud. (St. Bonaventure)., vol. 14, no. 2, pp. 43-65, 2001.

[66] G. Parker and M. Van Alstyne, "Innovation, openness, and platform control," Manage. Sci., vol. 64, no. 7, pp. 3015-3032, 2018.

[67] J. Wilkinson, "Fair trade: Dynamic and dilemmas of a market oriented global social movement," J. Consum. Policy, vol. 30, no. 3, pp. 219-239, 2007.

[68] W. W. Powell and J. A. Colyvas, "Microfoundations of institutional theory," Sage Handb. Organ. institutionalism, vol. 276, p. 298, 2008. 